\title{
Effect of Bovine Type-I Collagen-Based Films Containing Red Propolis on Dermal Wound Healing in Rodent Model
}

\author{
Efecto de Películas a Base de Colágeno Bovino Tipo I que Contienen Propóleo Rojo \\ sobre la Cicatrización de la Herida Cutánea en un Modelo Roedor
}

\begin{abstract}
",** Ricardo Luiz Cavalcanti de Albuquerque-Júnior; "André Luiz Santos Barreto; "Jônatas Almeida Pires; ;,***Francisco Prado Reis; ${ }^{*, * *}$ Sônia Oliveira Lima; ${ }^{* * * *}$ Maria Amália Gonzaga Ribeiro $\&{ }^{* *, * * * * *}$ Juliana Cordeiro Cardoso
\end{abstract}

\begin{abstract}
ALBUQUerQUE-JÚNIOR, R. L. C.; BARRETO, S. A. L.; PIRES, A. J.; REIS, P. F.; LIMA, O. S.; RIBEIRO, G. M. A. \& CARDOSO, C. J. Effect of bovine type-I collagen-based films containing red propolis on dermal wound healing in rodent model. Int. J. Morphol., 27(4):1105-1110, 2009.
\end{abstract}

SUMMARY: Propolis, an apitherapic product widely employed in natural medicine, presents various biological properties, such as bactericidal and anti-inflammatory activities, but only few reports have looked at the Brazilian red propolis variety. Collagen films have been employed to improve wound healing and some studies have investigated the effect of natural products incorporated into these films. Thus, the aim of this study was to analyze the effect of collagen-based films containing red propolis on wound healing. Therefore, wounds performed in the back of rats were dressed with collagen-based films (G2), and collagen-based films containing red propolis (G3); undressed worked as control (G1). After 3, 7 and 14 days the animals were euthanized, and the wounds were microscopically evaluated. In 7 days, G3 showed switch of the inflammatory profile from acute into chronic, increased plasma cells differentiation, replacement of Type-III for type-I collagen fibers, and better architectural organization of those fibers. Furthermore, a slight tendency for a better epithelization was verified in G3, but it was not statistically significant. Also in 7 days, the microvessels count was higher in G1 than in $\mathrm{G} 2(\mathrm{p}=0.000)$ and $\mathrm{G} 3(\mathrm{p}=0.001)$, but similar between the last groups $(\mathrm{p}=0,15)$, whereas the microvessels perimeter was higher in $\mathrm{G} 1$ than in $\mathrm{G} 2(\mathrm{p}=0.000)$ and $\mathrm{G} 3(\mathrm{p}=0.002)$, but equivalent in $\mathrm{G} 2$ and $\mathrm{G} 3(\mathrm{p}=0.175)$ in 14 days. In conclusion, the incorporation of Brazilian red propolis into collagen-based films was able to improve wound healing, probably by modulating the dynamics of the inflammatory evolution and collagen deposition process.

KEY WORDS: Propolis; Wound healing; Occlusive dressings; Type-I collagen.

\section{INTRODUCTION}

Wound healing is a complex phenomenon characterized by a sequence of independent and overlapped events described as exsudative/inflammatory, proliferative and remodeling phases. When there is significant loss of substance and the edges of the wound cannot be jointed, the cicatrization is considerably slower (second intention wound healing), since it is necessary the formation of granulation tissue before the collagenization process takes place and scar is ultimately formed (Diegelmann \& Evans, 2004).

Collagen-based films have been employed to improve the cicatricial repair of dermal mechanical and chemical damages. Besides the excellent biocompatibility, some studies have been carried out in order to incorporate bioactive compounds into collagen-based films. These materials are supposed to provide drug controlled release within the target tissue, accelerating the granulation tissue formation and epithelization process (Gopinath et al., 2004).

Propolis has been employed in improving the cicatricial repair (Sehn et al., 2009). Biological activities of propolis might be related to its antimicrobial, antiinflammatory and immunomudalatory properties (Castaldo \& Capasso, 2002). Despite propolis has been implied in cicatricial phenomena (McLennan et al., 2008), no study

Laboratory of Morphology, Science and Technology Institute, Aracaju, Sergipe/Brazil.

* Titular Professor of the Post-Graduation Program in Health and Environment, Tiradentes University, Aracaju, Sergipe/Brazil.

*** Adjunt Professor of the School of Dentistry, Federal University of Sergipe, Aracaju, Sergipe/Brazil.

${ }^{* * * * *}$ Laboratory of Biomaterials, Science and Technology Institute, Aracaju, Sergipe/Brazil. 
concerning the role played by Brazilian red propolis on wound healing have been reported so far.

Thus, the goal of this study was to analyze the effect of the association of bioactive type-I collagen films to $0.1 \%$ hydroalcoholic extract of red propolis on second-intention wound healing.

\section{MATERIAL AND METHOD}

Films preparation. Collagen was obtained from bovine tendon through treatment with $\mathrm{NaCl}$, acetic acid and pepsin (Cardoso, 2005). Hydroalcoholic extracts of red propolis was solubilized in polyethylene glycol 400 (PEG400), which was employed as cosolvent and plasticizer. This solution was mixed to $1 \%$ collagen dispersion in acetic acid $(0.5 \mathrm{~mol} / \mathrm{L})$ and the films were obtained by casting process. The final propolis concentration in the film was $0.1 \%$.

Surgical and histological procedures. Forty-five male Wistar rats $(250 \pm 50 \mathrm{~g})$, supplied with food and water ad libitum in a temperature and humidity-controlled environment, were anesthetized with intraperitoneal ketamine-xylazine $(100 \mathrm{mg} / \mathrm{kg}-5 \mathrm{mg} / \mathrm{kg})$ and $1 \mathrm{~cm} 2$ standard-sized square-shaped wounds were performed in the back of the animals. Rats were randomly assigned into three groups ( $n=15)$, as follows: $\mathrm{G} 1$, undressed wounds; G2, dressed with collagen-based films; and G3 dressed with collagen-based films containing red propolis. Five animals of each group were euthanized in $\mathrm{CO} 2$ chamber three, seven and 14 days after the surgical procedures and the wounded areas were removed and formalin-fixed. Surgical specimens were paraffin-embedded according to routine laboratorial techniques. Serial $5 \mu \mathrm{m}$ thick histological sections were obtained and stained by histochemical and immunohistochemical techniques.

Assessment of the inflammatory profile (IP) and epithelization process (ER). The IP was classified as acute (predominance of polymorphonuclear cells) and chronic (predominance of mononuclear cells), and graded as mild/ absent, moderate or severe. The ER was evaluated by measuring the epidermal migration from the normal wound margin to the point where the migrating epithelium stopped processing. ER (\%) was determined by the relation between the new epithelium present in the total wound and total area of wound.

Assessement of the collagen deposition. Histological sections stained in picrosirius and analyzed under polarized light were used to the descriptive analysis of the collagen deposition. Collagen fibers were analyzed according their birefringence pattern (greenish/yellow-greenish or orange, orange-reddish), morphological appearance (wavy or stretched, thin or thick, short or long) and disposition (parallel-arranged or interlaced).

Determination of microvessel count (MC) and microvascular perimeter (MP). Microvessels were detected by using a monoclonal antibody against the CD31 antigen (clone JC/70; 1:200, 12 h, Dako, Glostrup, Denmark). After washing in PBS, slides were incubated with biotin-labeled antimouse secondary antibodies (Vector Laboratories Inc., Burlingame, CA), then washed in PBS, and incubated with peroxidase-labeled streptavidin (DAKO). The reaction products were visualized by immersing the slides in freshly prepared diaminobenzidine (Dojindo, Kumamoto, Japan). Ten histological sections (x 100, 10 ocular, $0.739 \mathrm{~mm}^{2}$ per field) were randomly selected and the mean of MV was assessed. Furthermore, the mean of MP was determined in four high-power fields ( $\mathrm{x}$ 400) by using software for morphometry (Imagetool®).

Statistical analysis. Statistical significance of the quantitative measurement was assessed by analysis of variance (one-way ANOVA) and Tukey test. Each time point was analyzed separately, and two-tailed a-levels of $\mathrm{P}<0.05$ are significant.

Ethics aspects. In accordance to the institution's guidelines outlined in "Guide for the Care and Use of Laboratory Animals", it is hereby assured that all animals received humane care during all the steps of the experimentation. Furthermore, the study protocols were approved by our National Research Council prior to the beginning of the experiments.

\section{RESULTS AND DISCUSSION}

On the 3rd day, severe acute inflammatory reaction was observed in the top of wounds in all the three groups, although lymphocytic infiltration and immature granulation tissue was observed in the bottom (Fig. $1 \mathrm{Ia} / \mathrm{b} / \mathrm{c}$ ). These findings were expected, since soon after injury, as a result of vascular and biochemical changes, a substantial amount of neutrophils migrate into the wound to prevent the invasion and proliferation of microorganisms; subsequently, these polymorphonuclear cells are gradually replaced by mononuclear cells as the wound healing continues, in a bottom-top process (Diegelmann \& Evans). Scanty deposition of thin delicate reticularly arranged fibrils exhibiting greenish and yellow-greenish birefringence (type-III collagen) was observed in all the groups (Fig. $2 \mathrm{Ia} / \mathrm{b} / \mathrm{c}$ ). Inconspicuous deposition of collagen fibrils was expected, since the collagen 
synthesis begins around the 3rd day, in order to provide spatial orientation of angioblasts during the very early stages of wound healing (Ramos \& Miranda, 2007).

On the $7^{\text {th }}$ day, the inflammatory reaction was still severe in the three groups, but in G1 an acute infiltrate was still observed, whereas G2 and G3 presented exuberant granulation tissue (Fig. $1 \mathrm{IIa} / \mathrm{b} / \mathrm{c}$ ) suggesting that the use of such films apparently favored the installation of the early events of wound healing. As long both dress-wounded groups presented similar behavior regarding the IP, these findings appear to be related to mechanical protection of the wounds, which consequently would reduce bacterial contamination, and facilitate the development of the granulation tissue (Gopinath et al.). However, in G2 the infiltrate was predominantly lymphocytic, whereas it was plasma cell-rich in G3. These findings might be related to the immunomodulatory effects of Brazilian propolis, such as reduction of prostaglandin-induced chemotaxy and rapid phagocytosis-associated microbial elimination (Missima \& Sforcin, 2008), which would consequently improve the healing process by accelerating the immunological phenomena of B cells activation and differentiation into plasma cells. Type-III collagen was abundant in G1, whereas a mixed of type-III and type-I collagen was seen in G2 and G3. Type-I collagen was found in the bottom of the wounds, while in the top, type-III molecules were predominant. Type I-collagen fibers were thin delicate, slightly wavy and irregularly disposed in G2, whereas in G3, they were longer, thicker, sometimes outstretched, parallel arranged, although it presented a singular concentric pattern when deposited around blood vessels (Fig. $2 \mathrm{IIa} / \mathrm{b} / \mathrm{c}$ ). These findings suggest that the use of collagen-based dressing films led to more rapid replacement of type-III for type-I collagen molecules. This process might be related to the fact that the granulation tissue had already been installed in both groups at this time,
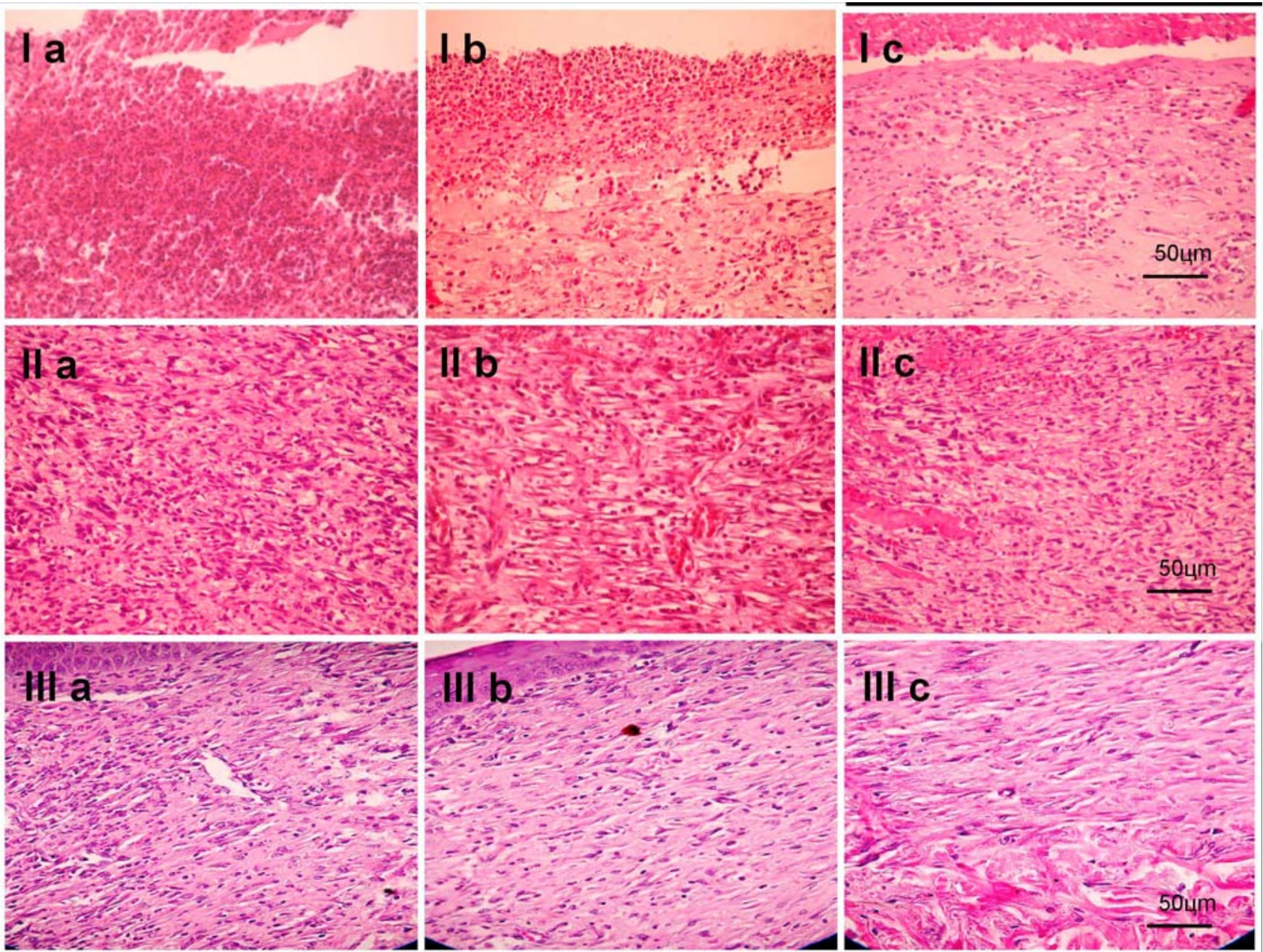

Fig. 1. Neutrophilic infiltration are seen in G1 (Ia), G2 (Ib) and G3 (Ic) in 3 days. Exuberant granulation tissue, still permeated by neutrophils in G1 (IIa), but not in G2 (IIb) and G3 (IIc) in 7 days; besides the granulation tissue is more mature in the latter. In 14 days, chronic infiltrate is still observed in G1 (IIIa) and quite less expressive in G2 (IIIb), whereas in G3 (IIIc) it is utterly inconspicuous (HE, 400x magnification). 

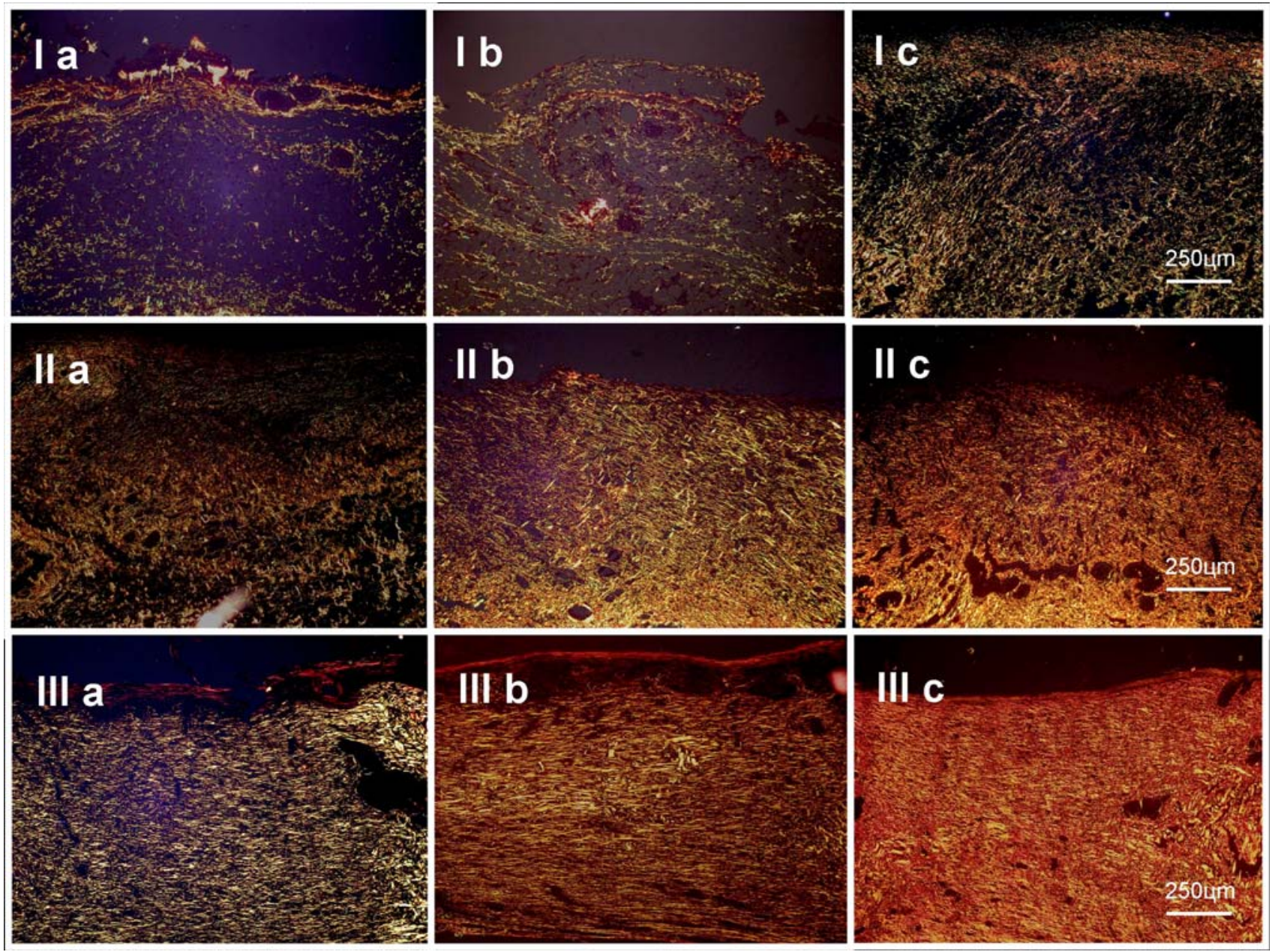

Fig. 2. Less conspicuous thin delicate reticularly-arranged type-III collagen fibrils are seen in G1 (Ia) than in G2 (Ib) and especially in G3 (Ic). In 7 days, the predominance of type-III collagen fibrils is maintained in G1 (IIa), and a mix of type-I and type-III fibers are observed in G2 (IIb), whereas type-III fibers are quite more apparent in G3 (IIc). Type-III collagen fibers are abundantly deposited in all groups in 14 days, but this deposition was less dense in G1 (IIIa) than in G2 (IIIb) and G3 (IIIc); Contrarily to the parallel arrangement seen in G1 and G2, the grosser orange-reddish collagen bundles observed in G3 are interlaced, resembling the normal dermis (Sirius Red/Polarization, 100x).
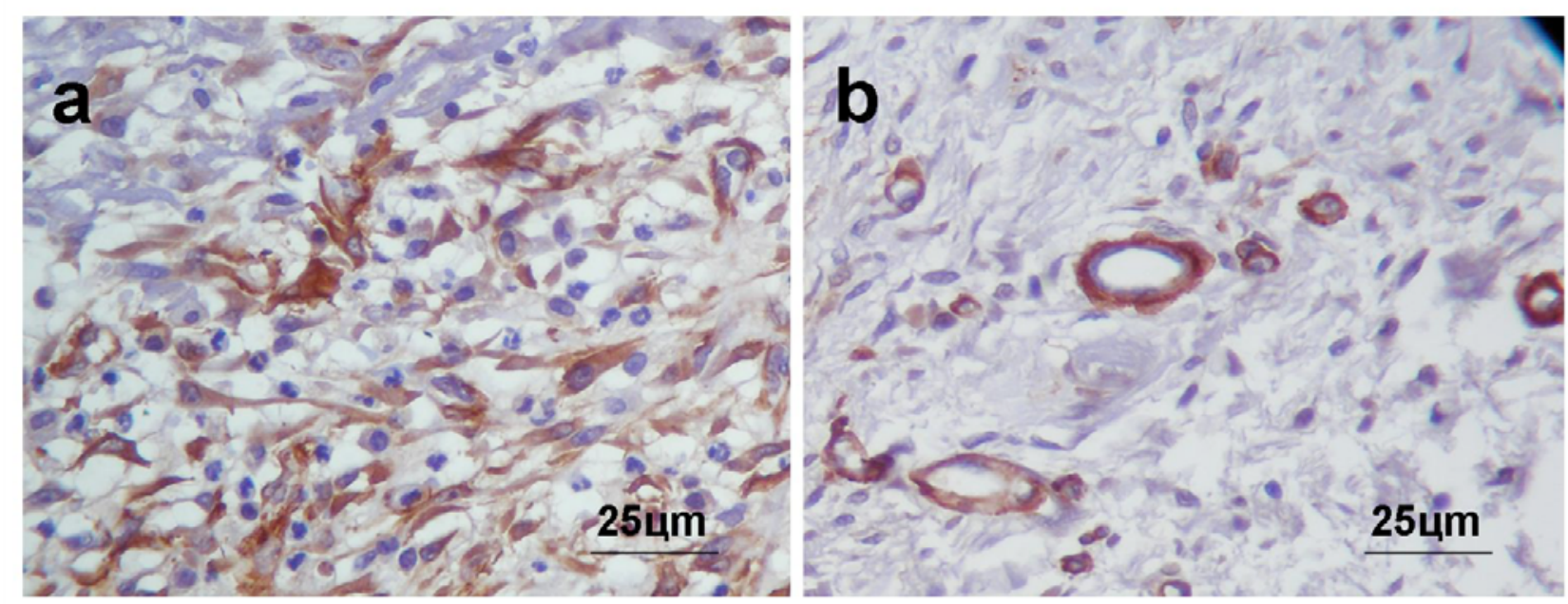

Fig. 3. (a) Identification of CD31 positive endothelial cells disperse within the immature granulation tissue, sometimes forming irregular compressed sinuous microvessels (G3/3 days). (b) Scattered well-formed capillary vessels lined by CD31 positive endothelial cells (G3/14 days) (SABC, 400x). 
so that endothelial growth orientation was no longer required. Besides, this replacement is extremely relevant to provide tensile force and mechanical stability of the connective tissue (Rich \& Whitaker, 2005). Moreover, the red propolis apparently induced a more regular and dense collagen arrangement in G3, suggesting that this natural product might favored fibroblastic proliferation and collagen deposition, and influence the pattern of collagenization.

On the $14^{\text {th }}$ day, $\mathrm{G} 1$ presented persistence moderate inflammatory reaction composed of lymphocytes and plasma cells, particularly in the top of the dermis. Oppositely, G2 and G3 presented inconspicuous infiltration of plasma cells along with some few microvessels. These data indicate that the use of dressing films provided substantial decrease in the residual inflammatory content, as reported in previous studies (Gopinath et al.). Nevertheless, no difference was verified between $\mathrm{G} 2$ and G3, suggesting that the most significant propolis-induced changes in the IP tended to occur in earlier stages of wound healing (Fig. $1 \mathrm{IIIa} / \mathrm{b} / \mathrm{c}$ ). Concerning collagenization, the three groups showed predominance of gross type-I fibers. In G1, those fibers were shorter, slightly wavy and parallelly disposed. Hypocollagenization of the wound surface was observed, suggesting a slower phenomenon of collagen deposition and remodelation. However, the wounds presented fullcollagenized in G1, the orange bundles assuming parallel arrangement and the reddish ones (mature type-I collagen) presenting perpendicularly disposed (Fig. $2 \mathrm{IIIa/b} / \mathrm{c})$. These findings ratify the stimulatory role played by collagen-based films on the scar formation reported in previous studies (Gopinath et al.). Despite a similar arrangement had been observed in G3, orange collagen fibers were thicker and more densely disposed, and the greater amount of reddish ones granted an interlaced appearance to the overall histological picture, resembling the normal dermis (Rich \& Whitaker). These data seem to support the theory that some constituents of propolis may play an important biomodulatory role on the dynamics of fibroblastic activity and collagen synthesis (McLennan et al.; Kilicoglu et al., 2008; Sehn et al.).

Therefore, the epithelization is considered a relevant step of wound healing, once keratinocytes are supposed to be source of cytokines involved in remodeling the collagen fibers deposited at the final stages cicatricial repair (Chong et al., 2009). In this study, the ER was incipient in the three groups on the 3rd day, but this process increased gradually to the 14th day. However, no statistically significant difference was observed among the means of the groups in $3(\mathrm{p}=0.13), 7(\mathrm{p}=0.2)$ and 14 days $(\mathrm{p}=0.19)$, suggesting that the dynamics of epithelization is not influenced by the use of the studied dressing films.

There was no significant difference in the $\mathrm{MC}$ among the groups on the 3 rd day $(p=0.07)$ and $14^{\text {th }}$ day $(p=0.19)$, but on the 7th day it was significantly higher in G1 than in G2 ( $\mathrm{p}=0.000)$ and $\mathrm{G} 3(\mathrm{p}=0.001)$, and similar between the last two groups $(\mathrm{p}=0.15)$ (figure 3$)$. The collagen-rich extracellular matrix deposited during the earlier stages of wound healing was proved to work as a complex reservoir of growth factors for angioblasts (Desmouliere et al., 1995). Therefore the findings observed in this study were expected, since this extracellular network was improved in both G2 and G3. However, as there was no difference between G2 and G3, it is supposed that red propolis at the studied dose did not influence the angiogenesis process. Despite green propolis had been previously proved to inhibit this process (Song et al., 2002), differences in the chemical composition of both varieties of propolis, as well as in the experimental model employed, might be responsible for this apparent paradox.

Regarding the MP, no significant difference was verified among the groups on the 3 rd day $(p=0.14)$ and $7^{\text {th }}$ day $(\mathrm{p}=0.21)$. On the $14^{\text {th }}$ day, MP was larger in $\mathrm{G} 1$ than in $\mathrm{G} 2(\mathrm{p}=0.000)$ and $\mathrm{G} 3(\mathrm{p}=0.002)$, but also there was no difference between the MC of the last two groups ( $\mathrm{p}=0.175$ ) (Table I). This phenomenon might be a result of the less intense collagen deposition seen in G1, since as long as the collagen fibers are deposited and matured, the small blood vessels are progressively compressed, reducing their perimeter, so that the endothelial cells go through apoptosis to form the less vascular scar (Ribeiro et al., 2009).

Our findings suggest that collagen films are useful to improve dermal second-intention wound healing. In addition, the incorporation of $0.1 \%$ hydroalcoholic extract of Brazilian red propolis to these films apparently stimulates the cicatricial fibroplasia, without toxic effects. Thus, these films may be considered a promising new dressing for wound occlusion and tissue repairing.

Table I. Mean of microvessels count (MC) and microvessels perimeter (MP) in the histological sections of G1, G2 and G3 on the 3rd, $7^{\text {th }}$, and $14^{\text {th }}$ days after the surgical procedures.

\begin{tabular}{ccccccc}
\multirow{2}{*}{$\begin{array}{c}\text { Time } \\
\text { (days) }\end{array}$} & \multicolumn{2}{c}{ Microvessel count $(\mathrm{mean} \pm \mathrm{SD})$} & \multicolumn{2}{c}{ Microvessel perimeter $(\mathrm{mean} \pm \mathrm{SD}) / \mu \mathrm{m}$} \\
\cline { 2 - 7 } & $\mathrm{G} 1$ & $\mathrm{G} 2$ & $\mathrm{G} 3$ & $\mathrm{G} 1$ & $\mathrm{G} 2$ & $\mathrm{G} 3$ \\
\hline 3 & $3,3 \pm 2,2$ & $4,1 \pm 2,6$ & $4,6 \pm 3,2$ & $407,7 \pm 234,4$ & $373,3 \pm 177,1$ & $371,9 \pm 172,5$ \\
7 & $14,2 \pm 7,3$ & $7,7 \pm 4,7$ & $8,4 \pm 5,6$ & $684,3 \pm 287,0$ & $726,2 \pm 280,9$ & $706,9 \pm 276,7$ \\
14 & $5,9 \pm 4,3$ & $6,7 \pm 3,1$ & $4,0 \pm 2,9$ & $1295,4 \pm 676,4$ & $810,1 \pm 422,9$ & $796,5 \pm 550,1$
\end{tabular}


ALBUQUERQUE-JÚNIOR, R. L. C.; BARRETO, S. A. L.; PIRES, A. J.; REIS, P. F.; LIMA, O. S.; RIBEIRO, G. M. A. \& CARDOSO, C. J. Efecto de películas a base de colágeno bovino tipo I que contienen propóleo rojo en la cicatrización de la herida cutánea en un modelo roedor. Int. J. Morphol., 27(4):1105-1110, 2009.

RESUMEN: El propóleo es un producto apiterápico ampliamente usado en medicina natural, que presenta diversas propiedades biológicas, como actividad bactericida y anti-inflamatoria, pero pocos informes han examinado la variedad brasileña del propóleo rojo. Películas de colágeno han sido empleadas para mejorar la cicatrización de heridas y en algunos estudios se ha investigado el efecto de los productos naturales incorporados en estas películas. Así el objetivo de este estudio fue analizar el efecto de las películas a base de colágeno que contienen propóleo rojo en la cicatrización de heridas. Heridas realizadas en el dorso de ratas fueron revestidas con películas a base de colágeno (G2) y con películas a base de colágeno con propóleo rojo (G3), heridas sin revestimiento fueron utilizadas como control (G1). Después de 3, 7 y 14 días, las heridas fueron evaluadas microscópicamente. A los 7 días G3 mostró un cambio del perfil de la respuesta inflamatoria de aguda a crónica, con aumento de la diferenciación de las células plasmáticas, sustitución de fibras de colágeno tipo III por tipo I con mejora de la organización arquitectónica de estas fibras. Además, una ligera tendencia a una mejor epitelización se verificó en G3, pero no fue estadísticamente significativa. También a los 7 días, el conteo de microvasos fue mayor en $\mathrm{G} 1$ que en $\mathrm{G} 2(\mathrm{p}=0,000)$ y $\mathrm{G} 3(\mathrm{p}=0,001)$, pero similar entre los últimos grupos $(\mathrm{p}=0,15)$, mientras que el perímetro de los microvasos fue mayor en G1 que en $\mathrm{G} 2(\mathrm{p}=0,000)$ y $\mathrm{G} 3(\mathrm{p}=0,002)$, pero equivalente en $\mathrm{G} 2$ y $\mathrm{G} 3$ (p=0,175) en 14 días. En conclusión, la incorporación de la variedad brasileña de propóleo rojo en películas a base de colágeno fue capaz de mejorar la cicatrización de la herida, probablemente por la modulación de la dinámica de la evolución inflamatoria y del proceso de depósito de colágeno.

PALABRAS CLAVE: Propóleo; Cicatrización de heridas; Películas oclusivas; Colágeno tipo-I.

\section{REFERENCES}

Cardoso, J. C. Modificação do colágeno pela reação de Maillard e avaliação de formulações na forma gel desenvolvidas a partir do material modificado. Doctoral thesis, Universidade de são Paulo, Faculdade de Ciências Farmacêuticas de Ribeirão Preto, 2005.

Castaldo, S. \& Capasso, F. Propolis, an old remedy used in modern medicine. Fitoterapia, 73(1):S1-6, 2002

Chong, H. C.; Tan, M. J.; Philippe, V.; Tan, S. H.; Tan, C. K.; Ku, C. W.; Goh, Y. Y.; Wahli, W.; Michalik, L. \& Tan, N. S. Regulation of epithelial-mesenchymal IL-1 signaling by PPARbeta/delta is essential for skin homeostasis and wound healing. J. Cell Biol., 184(6):817-31, 2009.

Desmouliere, A.; Redard, M.; Darby, I. \& Gabbiani, G. Apoptosis mediates the decrease in cellularity during the transition between granulation tissue and scar. Am. J. Pathol., 146(1):56-66, 1995.

Diegelmann, R. F. \& Evans, C. M. Wound healing an overview of acute, fibrotic and delayed healing. Front Biosci., 9(1):283-9, 2004.

Gopinath, D.; Ahmed, M. R.; Gomathi, K.; Chitra, K.; Sehgal, P. K. \& Jayakumar, R. Dermal wound healing processes with curcumin incorporated collagen films. Biomaterials, 25(10):1911-7, 2004.

Kilicoglu, S. S.; Kilicoglu, B. K. \& Erdemli, E. Ultrastructural view of colon anastomosis under propolis effect by transmission electron microscopy. World J. Gastroenterol., 14(30):4763-70, 2008.

McLennan, S. V.; Bonner, J.; Milne, S.; Lo, L.; Charlton, A.; Kurup, S.; Jia, J.; Yue, D. K. \& Twigg, S. M. The anti-inflammatory agent Própolis improves wound healing in a rodent model of experimental diabetes. Wound Repair Regen., 16(5):706-13, 2008.

Missima, F. \& Sforcin, J. M. Brazilian propolis action on macrophages and lymphoid organs of chronically stressed mice. Evid. Based Complement Alternat. Med., 5(1):71-5, 2008.

Ramos, A. F. N. \& Miranda, J. L. Propolis: a review of its antiinflammatory and healing actions. J. Venom. Anim. Toxins Incl. Trop. Dis., 13(4):697-710, 2007.

Rich, L. \& Whitaker, P. Collagen and picrosirius red staining: a colorized light assessment of fibrillar hue and spatial distribution. Braz. J. Morphol. Sci., 22(2):97-104, 2005.

Ribeiro, M. A.; Albuquerque, R. L.; Ramalho, L. M.; Pinheiro, A. L.; Bonjardim, L. R. \& Da Cunha, S. S. Immunohistochemical Assessment of Myofibroblasts and Lymphoid Cells During Wound Healing in Rats Subjected to Laser Photobiomodulation at 660 nm. Photomed. Laser Surg., 27(1):49-55, 2009.

Sehn, E.; Hernandes, L.; Franco, S. L.; Gonçalves, C. C. \& Baesso, M. L. Dynamics of reepithelialisation and penetration rate of bee própolis formulation during cutaneous wounds healing. Acta Chim. Acta, 635(1):115-20, 2009.

Song, Y. S.; Park, E. H.; Jung, K. J. \& Jin, C. Inhibition of angiogenesis by propolis. Arch. Pharm. Res., 25(4):500-4, 2002.

\section{Correspondence to:}

Ricardo Luiz C. Albuquerque Júnior

Av. Murilo Dantas, 300 Campus II / Prédio do ITP

Farolândia Aracaju/ Sergipe CEP 49032-490

BRAZIL

\section{Fone/fax number: 557932182190}

Email: ricardo.patologia@uol.com.br

Received: 04-07-2009

Accepted: 22-10-2009 